\title{
Water and Irrigation Requirement for Watermelon (Citrullus lanatus) Crop of North Central Plateau Zone of Odisha
}

\author{
Hembram $\mathrm{P}^{1^{*}}$, Suibudhi $\mathrm{CR}^{2}$, R.Subudhi ${ }^{1}$ \\ ${ }^{1}$ Ex Student, ${ }^{2}$ Professor, Dept of SWCE, CAET, OUAT, Bhubneswar-751003, Odisha, India \\ *Corresponding Author \\ Hembram P
}

Article History

Received: 21.06.2020

Accepted: 01.07.2020

Published: 12.07.2020

\begin{abstract}
The crop water requirement (CWR) and irrigation requirement (IR) of watermelon was calculated using a web based software. Relevant crop coefficients $(\mathrm{Kc})$, duration of crops and cropping pattern were used to calculate CWR from ETo. These coefficients present the relationship between references (ETo) and crop evapotranspiration (ET crop) or ET crop $=\mathrm{Kc} *$ ETo. The covered area of all crops (canopy cover) was collected. The Kc values were taken from FAO. The CWR were calculated for the north central plateau zone of Odisha for which climatic data were available and were applied to the nearest Research station. The effective rainfall was calculated with web based software by using FAO conversion table. The CWR and IR value was also calculated through this web based software Water requirement of watermelon, is $343 \mathrm{~mm}$ and Irrigation requirement of this crop is $271 \mathrm{~mm}$. in this zone 2 . By using the software a farmer of this zone can find out the water requirement and irrigation requirement by giving the crop name according to their season and duration of crop.
\end{abstract}

Keywords: Crop water requirement, Irrigation Requirement, Watermelon.

\section{INTRODUCTION}

India with its large population is facing unique challenges of water scarcity due to diverse geographical, climatic and geo-environmental conditions apart from unequal spatio-temporal distribution of fresh water resources. Therefore efficient and effective water management strategies are essential for meeting the increasing water needs of agricultural, domestic, industrial and environmental sectors. Considering the current water resources problems and rapid increase in its demand, the importance of effective utilization of water resources cannot be underestimated if India has to remain self-reliant in food production. Agriculture is the major user of water, improving agricultural water management is essential. Generally, yield decreased by $50 \%$ due to water stress. Efficient agricultural water management requires reliable estimation of crop water requirement. Crop need available water sufficiently and at the right time during its growth stages. However, irrigation scheduling has been based on the predicted crop water requirements (CWR). Which is amount of water needed to supply its evapotranspiration needs from planting to harvest for a given crop in a specific climate regime? When adequate soil water is maintained by rainfall and/or irrigation, it does not limit plant growth and crop yield. CWR is calculated for a given crop under the different climatic conditions defined that CWR is the depth (or amount) of water needed to meet the water loss through evapotranspiration. Abdelhadi et al. [1] estimated the crop water requirements (CWRs) of Acala cotton in the Gezira area of Sudan by taking recommended Penman-Monteith reference crop evapotranspiration $\left(\mathrm{ET}_{0}\right)$ with derived crop coefficients $(\mathrm{Kc})$ from the phenomenological stages of Acala cotton. Beyazgu et al. [2] studied an inter-comparison on evapotranspiration (ET), six methods for estimating the reference ET had been applied on a cotton field in the Gediz Basin, Turkey. Irmak et al. [3] compared the performances of solar and net radiation based methods with other methods. The performance of the derived equations was evaluated for 6 years (1995-2000) including dry and wet years, for the same site and for other humid locations in the Southeast United States. Yin et al. [4] calibrated the empirical equation to estimate radiation by taking observed solar radiation of 81 meteorological stations over China during (1971-2000). Nazeer [5] studied CROPWAT simulation under irrigated and rainfed conditions for maize crop in order to provide information necessary in taking decisions on irrigation management. The model was used to calculate evapotranspiration and crop water

Copyright @ 2020: This is an open-access article distributed under the terms of the Creative Commons Attribution license which permits unrestricted use, distribution, and reproduction in any medium for non commercial use (NonCommercial, or CC-BY-NC) provided the original author and source are credited. 
requirements for improved irrigation practices, planning of irrigation schedules under varying water supply conditions and the yield reduction under various conditions.

The aim of present study is to estimate the crop water and irrigation requirement of Watermelon crop by using a web based software. This software first calculates ETo value and effective rainfall which is necessary for estimation of CWR and IR. Espada for et al. [5] estimated reference evapotranspiration $\left(\mathrm{ET}_{0}\right)$ by taking a data set consisting of observed daily values of air temperature, relative humidity, sunshine duration and wind speed from eight weather stations in Andalusia and covering the period 1960-2005. Perez et al. [6] finds that onion seasonal water requirements are highly variable depending on agro climate, location and season, as are the crop coefficients $\left(K_{c}\right)$ which range from 0.4 to 0.7 (initial stage), 0.85 to 1.05 (middle development) and 0.6 to 0.75 (final stage). Esquiva et al. [5] design and developed a new web application with two different color segmentation techniques to estimate the percentage of green cover.

\section{ObJectives of The STUdy}

To find out water requirement and irrigation requirement of Watermelon in North Central Plateau Zone of Odisha season wise and duration wise.

\section{Matertials And Methods Study Area}

This experiment was conducted at College of Agricultural Engineering and Technology, Odisha University of Agriculture and Technology, Bhubaneswar during 2017 under the Dept of Soil and water conservation engineering for PG thesis work. North central plateau zone is taken as the study area for this study. Which latitude is $22^{\circ} 01^{\prime} 07.84^{\prime \prime} \mathrm{N}$ and longitude is $86^{\circ} 24^{\prime} 52.66^{\prime \prime E}$ with mean annual rainfall $1535 \mathrm{~mm}$. This zone has 2 distrticts Keonjhar and Mayurbhanj. Research station of this zone is located at Keonjhar district (Fig.1).

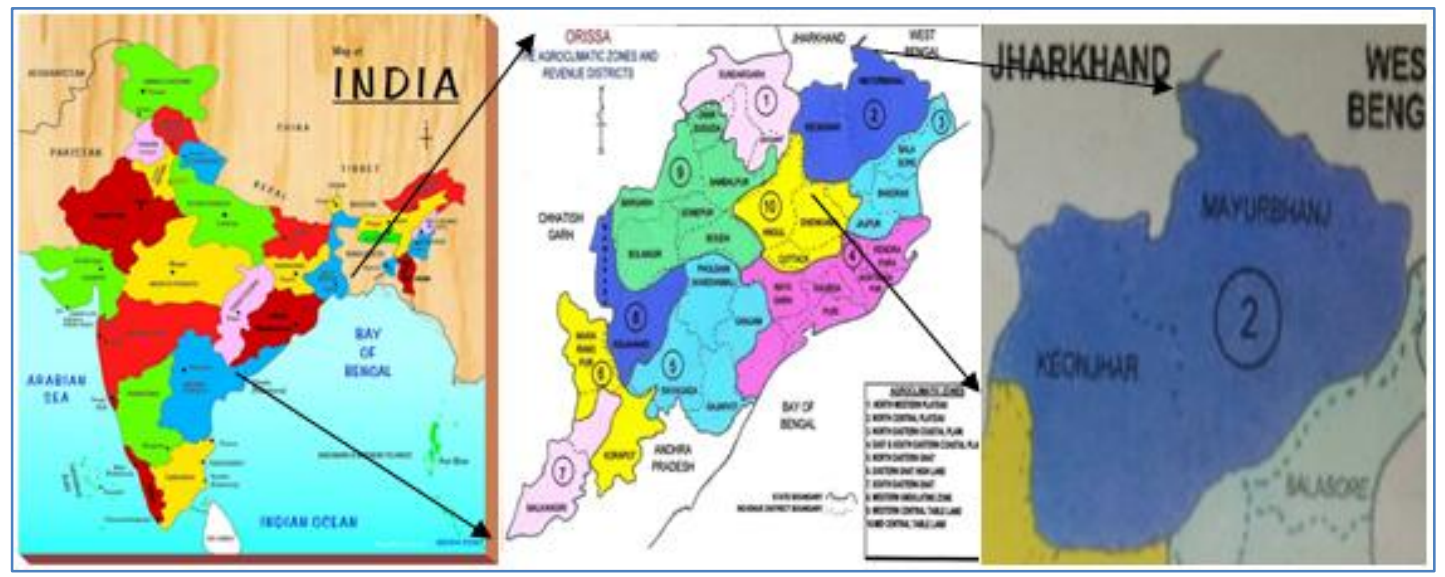

Fig-1: Map of different Agro-climatic zones of Odisha

\section{Calculation of ETo}

For calculation of ETo Climatic data maximum and minimum temperature, relative humidity, sunshine duration and wind speed are required.

The water needs for other crops are directly linked to the climatic parameter. For calculation of ETo, the Penman-Monteith Method was recommended.

The Penman-Monteith form of the combination equation is

$$
\mathrm{ETo}=\frac{0.40 \Delta(R n-G)+\gamma \frac{900}{T+273}}{\Delta+\gamma(1+0.32 U 2)} U 2(e s-e a)
$$

Where

$\mathrm{ETo}=$ reference evapotranspiration $(\mathrm{mm} /$ day $)$

$\mathrm{Rn}=$ net radiation at the crop surface $\left(\mathrm{MJ} / \mathrm{m}^{2} /\right.$ day $)$

$\mathrm{G}=$ soil heat flux density $\left(\mathrm{MJ} / \mathrm{m}^{2} /\right.$ day $)$

$\mathrm{T}=$ mean daily air temperature at $2 \mathrm{~m}$ height $\left({ }^{0} \mathrm{C}\right)$

$\mathrm{U} 2=$ wind speed $(\mathrm{m} / \mathrm{s})$

$e_{s}=$ saturation vapour pressure $(\mathrm{kPa})$ 
$e_{a}=$ actual vapour pressure $(\mathrm{kPa})$

$e_{s}-e_{a}=$ saturation vapour pressure deficit $(\mathrm{kPa})$

$\Delta=$ slop vapour pressure curve $\left[\mathrm{kPa}^{\circ} \mathrm{C}^{-1}\right]$

$\gamma=$ psychometricconstant. $\left[\mathrm{KPa}^{\circ} \mathrm{C}^{-1}\right]$

\section{Climate Data Collection}

In order to calculate ETo, the respective climatic data (1979-2002) was collected from the website http://global weather. tamu.edu/home/view/13292. The climatic data includes maximum and minimum temperature in $\left({ }^{0} \mathrm{C}\right)$, Relative Humidity data [in percentage], Average Daily Wind speed data in $(\mathrm{m} / \mathrm{s})$, sunshine duration in hours are taken.

\section{Temperature data}

Mean Daily Maximum $\left(\mathrm{Tmax},{ }^{0} \mathrm{C}\right)$ and Minimum Temperature $\left(\operatorname{Tmin},{ }^{0} \mathrm{C}\right)$,

$\mathrm{T}=$ mean daily air temperature

$$
T=\frac{\operatorname{Tmax}+\mathrm{Tmin}}{2}
$$

\section{Net solar radiation Calculation $(\mathbf{R n})$}

The net radiation $(\mathrm{Rn})$ is the difference between the incoming net shortwave radiation (Rns)and the outgoing net longwave radiation $(\mathrm{Rnl})$ :

$$
\mathrm{Rn}=\mathrm{Rns}-\mathrm{Rnl}
$$

Where Rn,Rns, Rnl in the above equation are expressed in $\mathrm{MJ} / \mathrm{m}^{2} / \mathrm{day}$.

\section{Calculation of incoming net shortwave radiation (Rns)}

$$
\text { Rns }=(1-\propto) \text { Rs }
$$

WhereRns net solar or shortwave radiation $\left[\mathrm{MJ} / \mathrm{m}^{2} /\right.$ day $]$,

Rs the incoming solar radiation $\left[\mathrm{MJ} / \mathrm{m}^{2} / \mathrm{day}\right]$.

Rs=shortwave radiation, $\left[\mathrm{MJ} / \mathrm{m}^{2} / \mathrm{day}\right]$

$$
\text { Rs }=\left(0.25+0.50 \frac{\mathrm{n}}{\mathrm{N}}\right) \mathrm{Ra}
$$

$\mathrm{Ra}=$ extraterrestrial radiation, values of $\mathrm{Ra}$ in $(\mathrm{mm} / \mathrm{day})$ calculated for different months and latitudes are given in Table a and $\mathrm{b}$.

$\propto=n / N$ is the ratio between actual measured bright sunshine hours and maximum possible sunshine hours. Values of $\mathrm{N}$ calculated for different months and latitudes are given in Table $\mathrm{c}$. Where $\mathrm{n}$, actual measured bright sunshine hours values are collected from climate data. Both $\mathrm{n}$ and $\mathrm{N}$ expressed in mean daily values, in hours. The value of Rs is calculated in $\mathrm{mm} /$ day. We have to convert it to $\mathrm{MJ} / \mathrm{m}^{2} /$ day.

$$
1 \mathrm{~mm} / \mathrm{day}=2.45 \mathrm{MJ} / \mathrm{m}^{2} / \text { day }
$$

\section{Calculation of outgoing net longwave radiation (Rnl)}

Where,

$$
\mathrm{Rnl}=\mathrm{f}(\mathrm{T}) \times f(\text { ed }) \times f\left(\frac{\mathrm{n}}{\mathrm{N}}\right)
$$

$\mathrm{f}(\mathrm{T})=$ Effect of temperature on long wave radiation $(\mathrm{Rnl})$,Table $\mathrm{d}$.

$\mathrm{f}(\mathrm{ed})=$ Effect of vapor pressure on long wave radiation $(\mathrm{Rnl})$,Table e.

$f(n / N)=E f f e c t$ of the Ratio of actual and maximum bright sunshine hours on long wave radiation (Rnl), Table $f$.

\section{Soil heat flux (G)}

The soil heat flux, G, is the energy that is utilized in heating the soil. $G$ is positive when the soil is warming and negative when the soil is cooling. Although the soil heat flux is small compared to Rn and may often be ignored, the amount of energy gained or lost by the soil in this process should theoretically be subtracted or added to Rn when estimating evapotranspiration. As the magnitude of the day or ten-day soil heat flux beneath the grass reference surface isrelatively small, it may be ignored Gday $\approx 0$ 


\section{Calculation of pshychromatic constant $\gamma$}

Where, $\mathrm{P}=$ atmospheric pressure $(\mathrm{Kpa})$

$$
\begin{gathered}
\gamma=0.665 \times 10^{-3} P \\
P=\left(\frac{293-0.0065 Z}{293}\right)^{5.26}
\end{gathered}
$$

$\mathrm{Z}=$ elevation above sea level $(\mathrm{m})$

\section{Calculation of Slope vapour pressure curve $\Delta$}

$\Delta=$ slope vapour pressure curve $\left[\mathrm{kPa}{ }^{\circ} \mathrm{C}^{-1}\right]$

$$
\Delta=\frac{4098\left[0.6108 \exp \left(\frac{17.27 T}{T+237.3}\right)\right]}{(T+237.3)^{2}}
$$

$\mathrm{T}=$ air temperature $\left[{ }^{\circ} \mathrm{C}\right]$,

\section{Calculation of saturation vapour pressure deficit $\left(e_{s}-e_{a}\right)$ :}

$e_{s}=$ saturation vapour pressure $(\mathrm{kPa})$

$$
\begin{gathered}
e_{s=} \frac{e^{0}(\text { Tmax })+e^{0}(\text { Tmin })}{2} \\
e_{a}=e_{s} \frac{\text { RHmean }}{100}
\end{gathered}
$$

$e_{a}=$ actual vapour pressure $(\mathrm{kPa})$

$e^{0}(\operatorname{Tmax})=$ saturation vapour pressure at daily maximum temperature $(\mathrm{kPa})$

$e^{0}(\mathrm{Tmin})=$ saturation vapour pressure at daily minimum temperature $(\mathrm{kPa})$,

RH= Relative Humidity (\%)

$$
\begin{aligned}
e^{0}(\text { Tmax }) & =0.6108 \exp \left[\frac{17.27 T \max }{\operatorname{Tmax}+17.27}\right] \\
e^{0}(\text { Tmin }) & =0.6108 \exp \left[\frac{17.27 T \min }{\operatorname{Tmin}+17.27}\right]
\end{aligned}
$$

\section{Calculation of Effective rainfall}

The rainfall contributes to a greater or lesser extent in satisfying CWR, depending on the location. So how much amount of rainfall effectively used by the crop after rainfall losses due to surface run off and deep percolation was determined. The precipitation data were required for software (daily, decade or monthly Rainfall). For effective rainfall calculation, rainfall data records from a range of years (1979-2002) were collected from nearest climatic research station. Monthly irrigation requirement of selected crops has been calculated by deducting ETc values from the effective precipitation. Effective precipitation is obtained from the rainfall values, following FAO conversion table show in Table 3.

\section{Calculation of ETcrop}

For crop water needof North Central Plateau Zone of Odisha, information on the various crop characteristics data were collected.

Crop datacollected from the field:

1. Crop and crop variety

2. Sowing and harvestingdate.

3. Crop characteristics:

- $\quad$ Length of individual growth stages

- Crop factors, relating crop evapotranspiration to reference evapotranspiration.

The Crop duration is and crop stages are taken from Agril. Hand book and Kc values of the selected crops are taken from FAO 24, irrigation and drainage paper. Crop co-efficient Kc is the ratio between evapotranspiration of crop (Etc) and reference evapotranspiration and expressed as

$$
\text { ETcrop }=E T 0 \times K c
$$

\section{Calculation of Crop Water Requirement (CWR)}

Crop Waterrequirement (CWR) includes losses during the application of irrigation water to field (percolation, seepage, and run off) and water required for special operation such as land preparation, transplanting, leaching etc. Crop Water Requirement is

$$
C W R=E T c r o p+\text { application loss }+ \text { water needed for special operations }
$$




\section{Calculation of Irrigation Requirement}

Irrigation requirement is the total quantity of water applied to the land surface in supplement to the water supplied through rainfall and soil profile to meet the water needs of crops for optimum growth.

$\mathrm{IR}=\mathrm{CWR}-(\mathrm{ER}+\mathrm{S})$

$\mathrm{IR}=$ Irrigation requirement

CWR $=$ Crop Waterrequirement

$\mathrm{ER}=$ effective rainfall

$\mathrm{S}=$ soil profile contribution including that from shallow water tables

\section{RESUlT AND DisCUSSION}

Crop water requirement and Irrigation Requirement:

Reference Evapotranspiration $\left(\mathbf{E T}_{0}\right)$ Estimation

For the estimation of water and irrigation requirement of North Central Plateau Zone of Odisha, first calculation of ET0 was necessary. Daily climatic data were collected from 1979 to 2002. FAO-56 Penman-Monteith method used for ETo calculation. For calcualation of ETo climatic data like minimum and maximum air temperature, mean relative humidity, wind speed and sunshine hourof that zone are required. From table 4.1, it was observed that daily mean ETo was maximum during may $(6.89 \mathrm{~mm} /$ day $)$ and minimum during December $(3.12 \mathrm{~mm} /$ day $)$ in North Central Plateau Zone of Odisha and mean daily ETo value over the year was $4.61 \mathrm{~mm} / \mathrm{day}$.

\section{Effective rainfall Estimation}

For effective rainfall calculation, rainfall data records from a range of years (1979-2002) were collected from nearest climatic research station. Effective rainfall determination is always a top task. In this study, rainfall is converted to effective rainfall by following the rainfall effective rainfall relationship given in the website file:///E:/CHAPTER\%203\%20\%20EFFECTIVE\%20RAINFALL.html. The linear relation between rainfall and effective rainfall is shown fig. 2.

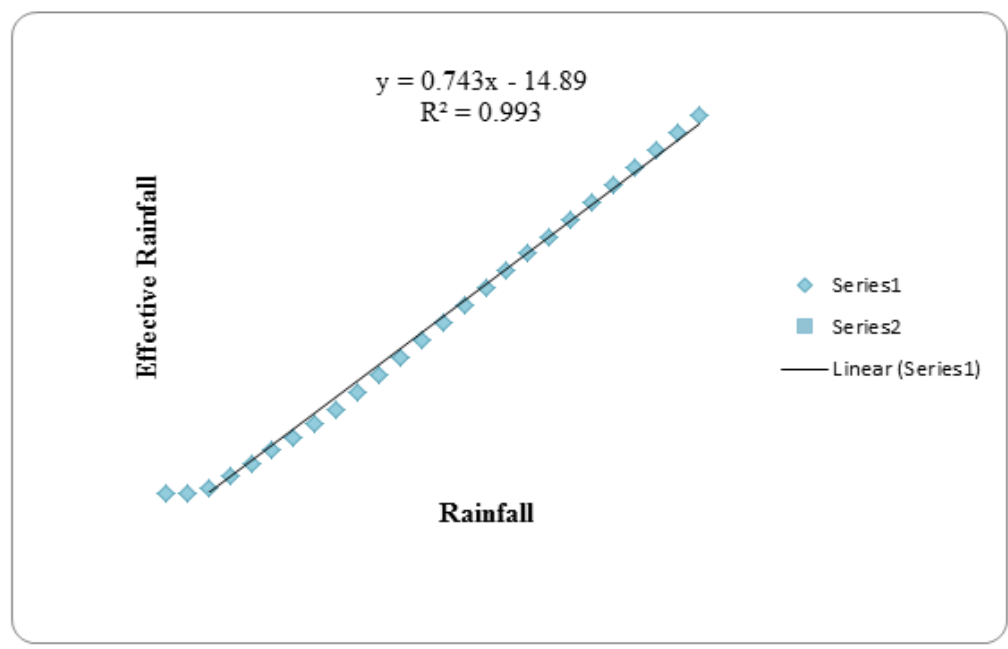

Fig-2: Relation between rainfall and effective rainfall

Then values of effective rainfall are calculated from the graph.

\section{ETcrop Value Calcualation}

The Crop duration is and crop stages are taken from Agril. Hand book and Kc values of the selected crops are taken from FAO 24, irrigation and drainage paper.

Kc values of the Watermelon for different season are shown in Table 1

Table-1: Kc Values of Watermelon

\begin{tabular}{|l|l|l|l|l|l|l|l|l|l|}
\hline CROPS & TOTAL & \multicolumn{4}{|l|}{ STAGES (IN DURATION) } & \multicolumn{3}{|l|}{ Kc VALUE FOR DIFFERENT STAGES } \\
\cline { 3 - 12 } & $\begin{array}{l}\text { DURATIO } \\
\text { NS }\end{array}$ & $\begin{array}{l}\text { Initial } \\
\text { stage } \\
\text { (I) }\end{array}$ & $\begin{array}{l}\text { lrop } \\
\text { Dev } \\
\text { (II) }\end{array}$ & $\begin{array}{l}\text { Mid } \\
\text { Stage } \\
\text { (III) }\end{array}$ & $\begin{array}{l}\text { Late } \\
\text { season } \\
\text { (IV) }\end{array}$ & $\begin{array}{l}\text { Initial } \\
\text { stage } \\
\text { (I) }\end{array}$ & $\begin{array}{l}\text { Crop } \\
\text { Dev } \\
\text { (II) }\end{array}$ & $\begin{array}{l}\text { Mid } \\
\text { Stage } \\
\text { (III) }\end{array}$ & $\begin{array}{l}\text { Late } \\
\text { season } \\
\text { (IV) }\end{array}$ \\
\hline Watermelon & 80 & 10 & 20 & 20 & 30 & 0.40 & 1.00 & 0.75 & 0.40 \\
\hline
\end{tabular}



expressed as

Crop co-efficient $\mathrm{Kc}$ is the ratio between evapotranspiration of crop (Etc) and reference evapotranspiration and

$$
\text { ETcrop }=E T 0 \times K C
$$

\section{CWR and IR estimation}

Crop Waterrequirement (CWR) includes losses during the application of irrigation water to field (percolation, seepage, and run off) and water required for special operation such as land preparation, transplanting, leaching etc. Crop Water Requirement is

$$
C W R=E T c r o p+\text { application loss }+ \text { water needed for special operations }
$$

Water needed for special operations are calculated as for Watermelon taking ETcrop 84\%, 12\% land preparation, $4 \%$ seepage loss in field channel including evaporation.

Irrigation requirement is the total quantity of water applied to the land surface in supplement to the water supplied through rainfall and soil profile to meet the water needs of crops for optimum growth.

$\mathrm{IR}=\mathrm{CWR}-(\mathrm{ER}+\mathrm{S})$

$\mathrm{IR}=$ Irrigation requirement

$\mathrm{CWR}=$ Crop Water requirement

$\mathrm{ER}=$ effective rainfall

$\mathrm{S}=$ soil profile contribution including that from shallow water tables.

\section{Water and irrigation requirement of all the crop season wise}

In water and irrigation requirement of Watermelon I, is given below Table 2, which was calculated by using web based software. Water requirement of watermelon, is $343 \mathrm{~mm}$ and Irrigation requirement of this crop is $271 \mathrm{~mm}$.

Table-2: Effective rainfall, crop water and irrigation requirement of crops in summer

\begin{tabular}{|c|c|c|c|c|}
\hline Crop Name & Crop variety & CWR, mm & ER, mm & IR, mm \\
\hline Watermelon 80 & Apoorva & 343.42 & 72.23 & 271.2 \\
\hline
\end{tabular}

\section{CONCLUSION}

Crop water and irrigation requirement of crops were estimated by using this Software. And following conclusions were found out from the study

1. Water requirement of watermelon, is $343 \mathrm{~mm}$ and Irrigation requirement of this crop is $271 \mathrm{~mm}$. in this zone 2

2. Software was developed for easily getting CWR and IR of crops season wise can be found.

\section{REFERENCES}

1. Abdelhadi, A. W., Hata, T., Tanakamaru, H., Tada, A., \& Tariq, M. A. (2000). Estimation of crop water requirements in arid region using Penman-Monteith equation with derived crop coeffcients: a case study on Acala cotton in Sudan Gezira irrigated scheme, Agricultural Water Management, 45: 203-214.

2. Beyazgu, M., Kayama, Y., \& Engelsman, F. (2000). Estimation methods for crop water requirements in the Gediz Basin of western Turkey, Journal of Hydrology, 229: 19-26.

3. Irmak, A., Irmak, S., \& Martin, D.L. (2008). Reference and Crop Evapotranspiration in South Central Nebraska. I: Comparison and Analysis of Grass and Alfalfa-Reference Evapotranspiration,Journal of irrigation and drainage engineering, 134(6): 690-699.

4. Yin, Y., Wu, S., Zhen, D., Yang, Q. (2008). Radiation calibration of FAO56 Penman-Monteith model to estimate reference crop evapotranspiration in China, Agricultural Water Management, 95: 77-84.

5. Nazeer, M. (2009). Simulation of maize crop under irrigated and rainfed conditions with CEROPWART model, ARPN Journal of Agricultural and Biological Science, 4(2).

6. Pérez, O.M., \& Knox, J.W. (2015). Water Relations and Irrigation Requirements of Onion (ALLIUM Cepa L.) : A Review of Yield and Quality Impacts ,Experimental Agriculture, 51( 2): 210-231. 